\title{
Problems and Countermeasures in the Cultivation of Innovation and Entrepreneurship Ability among College Students in China
}

\author{
Qiuxuan Gong* \\ Shandong Jiaotong University, Jinan 250000, Shandong Province, China \\ *Corresponding author: Qiuxuan Gong, 690370665@qq.com
}

\begin{abstract}
This article analyzes the current situation of cultivating innovation and entrepreneurship ability among college students in China. It found that the main reasons for the lack of innovation and entrepreneurship ability are from three aspects: inadequate awareness of innovation and entrepreneurship among college students; inadequate innovation and entrepreneurship ability among the team of teachers; colleges and universities lack systematic innovation and entrepreneurship courses. The discussion will be based on these three aspects from three perspectives, which include providing more practical opportunities and a good environment, building innovation and entrepreneurship tutor teams, as well as strengthening the construction of innovation and entrepreneurship courses, in order to assist in the cultivation of innovation and entrepreneurship ability among college students in China.
\end{abstract}

Keywords: College students; Innovation and entrepreneurship; Ability training

Publication date: August 2021; Online publication: August 30, 2021

\section{Introduction}

As the global economic system continues to develop and change today, the most cutting-edge science and technology as well as innovative talents would have all the opportunities. Countries around the world have launched innovation-driven development strategies, and China, not wanting to be left behind, is striving to be at the forefront of innovation and entrepreneurship on the international level. In the report at the $19^{\text {th }}$ National Congress, General Secretary Xi Jinping clearly pointed out that there is a need to speed up the building of an innovative country, in which he stressed that development is the first priority, talent is the first resource, innovation is the first driving force; thus, the importance of innovation is highly valued ${ }^{[1]}$. Ever since the premier, Li Keqiang, put forward the concept of "mass innovation and mass entrepreneurship," China has set off a wave of innovation and entrepreneurship, driving economic and social development through innovation and entrepreneurship in striving to build an innovation-oriented country. Innovation and entrepreneurship ability directly determines the success of innovation and entrepreneurship. As the most innovative and entrepreneurial high-level group, college students are the impetus of social development in the future. Cultivating the innovative and entrepreneurial spirit among college students to achieve a large number of innovative entrepreneurs, functions as a strong support and guarantee in building an innovation-oriented country ${ }^{[2]}$. However, the cultivation of innovation and entrepreneurship among college students in China is still in the initial stage of exploration. This paper analyzes the problems that exist in cultivating innovation and entrepreneurship ability among college students, as well as discusses specific measures to solve these problems. 
2. Current situation of the cultivation of innovation and entrepreneurship ability among college students

\subsection{Inadequate awareness of innovation and entrepreneurship among college students}

At present, college students' creative consciousness is weak, where most students just go with the flow. These students desire to seek stable high-income careers and do not wish to create new opportunities, which may be associated with the conservative thought of the Chinese traditional education. Most people choose to avoid all kinds of uncertainties in the process of innovation and entrepreneurship. Although some students have abundant ideas for innovation and entrepreneurship, they lack courage and confidence while worrying about their lack of ability, fear of failure, in addition to the lack of professional guidance and help. Other than those worries in regard to innovation and entrepreneurship, the schools' publicity and education on innovation and entrepreneurship are insufficient. Schools rarely carry out detailed and systematic propaganda on innovation and entrepreneurship. As a result of that, most students do not really understand the importance of innovation and entrepreneurship as well as the fruits that innovation and entrepreneurship may bring forth. Most students are not very active and those students that participate in innovation and entrepreneurship competitions are only a fraction of the whole school.

\subsection{Inadequate innovation and entrepreneurship ability among the team of teachers}

Teachers' degree of investment directly affects the cultivation of students' innovation and entrepreneurship ability. Many teachers are only immersed in scientific research and classroom education; they do not realize the importance of innovation and entrepreneurship for students, thus putting very little energy into these areas. Although many teachers have rich theoretical knowledge reserve, their knowledge reserve is not wide enough to achieve cross-integration of multiple disciplines. They are only able to provide guidance from one aspect rather than a systematic and comprehensive guidance for students. Most college teachers lack practical experience in business management as well as innovation and entrepreneurship. In many cases, the guidance for students are only on paper, which may be out of touch with reality and is unable to drive students' entrepreneurial enthusiasm, thus hindering the cultivation of innovation and entrepreneurship. Schools also lack evaluations in terms of innovation and entrepreneurship for teachers. The evaluations in many colleges and universities are restricted to the traditional type of evaluation, such as subject research, teaching projects, performance appraisal, etc., which is not conducive to the investment of teachers in guiding students' innovation and entrepreneurship.

\subsection{Lack of systematic innovation and entrepreneurship courses in colleges and universities}

Courses are important to realize the teaching goal. The quality of a course directly determines the teaching effect of innovation and entrepreneurship. Compared with foreign countries, the innovation and entrepreneurship curriculum in China started late and is still young. Although many colleges and universities have set up relevant courses, the development and design of the courses are scattered, the number is limited, and there is no systematic innovation and entrepreneurship curriculum system. Entrepreneurship courses between different disciplines lack penetration, and there are only a few universities which combine basic courses with practical courses. Even if there are related courses, the number of courses is very few. At the same time, universities in China lack unified teaching materials for innovation and entrepreneurship education, which is not suitable for the sustainable development of innovation and entrepreneurship education. The innovation and entrepreneurship education curriculum does not reflect a gradient design; it does not meet the needs of students with different backgrounds with low or high grades in regard to entrepreneurial knowledge. In the teaching process of innovation and entrepreneurship courses, teachers still focus on theoretical explanation, and lack the practice of combining 
theory and practical. Boring theoretical learning would not be able to mobilize students' learning enthusiasm. Students do not understand the purpose of learning, and they do not know how to use the knowledge learned so it is difficult for them to be interested in the contents. Innovation and entrepreneurship courses that are offered by many universities are not combined with students' major. The separation of innovation and entrepreneurship knowledge with professional knowledge does not have the opportunity to promote one another; thus, the teaching effect is substandard.

\section{Analysis on the countermeasures to improve college students' innovation and entrepreneurship ability}

\subsection{Providing more practice opportunities and a good atmosphere}

A good cultural environment for innovation and entrepreneurship is an external driving force to improve students' innovation and entrepreneurship ability, and it is a basic guarantee for the continuous success of innovation and entrepreneurship education. Schools can actively publicize national and local policies or measures via newspapers, broadcasts, campus networks, and other forms to promote entrepreneurship. Colleges and universities can also vigorously publicize about innovation and entrepreneurship or the achievements of teachers and students in relation to the former by means of campus network, publicity board, microblog, or other platforms so as to fully initialize the innovation and entrepreneurship environment on campus. Schools should encourage students to participate in various academic lectures and reports, organize visitations to successful enterprises, broaden their horizons, and mobilize students' enthusiasm for innovation and entrepreneurship. Schools can also establish a set of rules and regulations to encourage innovation and entrepreneurship among college students, such as credit recognition, awards, etc. The weak entrepreneurial awareness among college students is closely related to their lack of social experience ${ }^{[2]}$. In order to cultivate and improve students' innovation and entrepreneurship ability, it is necessary to provide more practical platforms to help students practice and promote the development of innovation and entrepreneurship. In schools, combined with professional training objectives and development direction, scientific research and practice societies related to the profession can be established. At the same time, schools can organize various academic activities between various professions to help students break the barriers between majors, extend their friendships, and broaden their knowledge. In addition, schools can also set up an entrepreneurial park in their compounds, cultivate a number of innovative ideas and entrepreneurial teams with potential, arrange workplaces for the entrepreneurial teams, establish a recyclable financial support system, and form an entrepreneurial base with the market environment. Other than that, schools should make full use of all kinds of potential educational resources and cooperate with off-campus enterprises to provide students with more practical opportunities. Through the cooperation between colleges and enterprises, the seamless connection between colleges and enterprises can be realized, and college students would be able venture out of their classrooms and schools to really participate in training and practice. In this way, it helps them to sort out their professional knowledge, enhance their professional ability, and enrich their practical experience. At the same time, students can use this platform to obtain relevant information provided by the enterprises to have a certain understanding of the needs of enterprises as well as the social and economic conditions in order to prepare for future business practices.

\subsection{Building innovation and entrepreneurship tutor teams}

The quality and achievement value of talent cultivation in colleges and universities depend on the teachers to a great extent. The cultivation of innovation and entrepreneurship ability among students is not possible without high-quality teachers. Therefore, it is necessary to strengthen the construction of innovation and 
entrepreneurship education teachers ${ }^{[3]}$. First of all, it is necessary to strengthen the professional training for teachers in schools, support teachers' temporary employment training, and encourage teachers to participate in the innovation and entrepreneurship practice of industries, enterprises, as well as research institutes. At the same time, the team of entrepreneurial tutors should not be limited to a single discipline. Only by establishing a multidisciplinary team of innovation and entrepreneurship tutors, these tutors can then complement each other and provide students with an all-round guidance. In addition, it is also necessary to strengthen the learning, exchange, and cooperation between tutor teams and the outside world. Teachers should be encouraged to conduct training or research on innovation and entrepreneurship, as well as visit more entrepreneurship training bases and incubators so as to make up for the lack of practical teaching experiences and form a relatively perfect cascade innovation and entrepreneurship guidance system.

Innovation and entrepreneurship tutors are not only restricted to teachers in schools, but also entrepreneurs, venture capitalists, government officials, successful entrepreneurs, and other part-time teachers from all walks of life in order to expand the teaching teams of innovation and entrepreneurship education. Through regular lectures and guidance from experts outside schools, relevant experiences in practice can be really passed on to students; helping students to translate theoretical knowledge into practice. Experts also need to explore deeper to understand students' thoughts to help them solve various problems on the road to innovation and entrepreneurship according to actual situations, thus realizing the growth of students in these aspects.

\subsection{Strengthening the construction of innovation and entrepreneurship courses}

Curriculum construction is an important prerequisite for education to achieve good results. The rationality of curriculum setting plays a key role in students' knowledge accumulation and practical development. Innovation and entrepreneurship education should be effectively incorporated into professional education as well as cultural quality education teaching plan and credit system ${ }^{[4]}$. A multilevel and three-dimensional curriculum system of innovation and entrepreneurship education should be established while professional disciplines and basic disciplines should be combined to form a training mode for all disciplines.

On the one hand, basic courses related to entrepreneurship should be offered to enable students to understand the current situation of entrepreneurship, policies, necessary psychological quality of personnel, and possible difficulties in the future. Policy guidance and other basic knowledge should be included into the teaching materials while authoritative and unified teaching materials for mass entrepreneurship and innovation education should be developed. Courses for mass entrepreneurship and innovation at different educational stages should be set up in a hierarchical way with different emphasis on professional ability.

On the other hand, it is necessary to guide, educate, and train students about the entrepreneurial theory and practice with the cultivation of students' innovative awareness and entrepreneurial ability as the core. Teaching has to induce creative interest, break thinking patterns, and cultivate pluralistic thinking. Only when students have a thirst for knowledge, their creative ability can then be stimulated. For example, important cases related to their major can be discussed to attract students' attention, guide them to move out of the existing thought of "keep no secrets from each other," and encourage them to be more imaginative. Tutors, whether in or out of schools, should change the traditional teaching mode. The traditional teaching mode is based on teachers, where students passively accept knowledge indoctrination. This directly leads to the phenomenon of classroom silence in colleges and universities, in which this phenomenon is not conducive only to the development of students' autonomous learning, but also the cultivation of innovative thinking. Student-centered teaching requires interaction between teachers and students to cultivate students' thinking via forming the habit of asking questions and exploring them. 


\section{Conclusion}

At present, although China is paying much more attention to the cultivation of innovation and entrepreneurship ability among college students, there are still many problems. It is necessary to further strengthen the environment of innovation and entrepreneurship, the innovation and entrepreneurship tutor teams, as well as the construction of innovation and entrepreneurship courses in order to further improve the innovation and entrepreneurship ability among college students.

\section{Disclosure statement}

The author declares that there is no conflict of interest.

\section{References}

[1] Xiao W, 2018, Xi Jinping Thought on Socialism with Chinese Characteristics for a New Era - Learn from Comrade Xi Jinping's Important Statement on the "Three Firsts" when He Participated in the Deliberations of the Guangdong Delegation. China Daily, (007).

[2] Liu Q, Liu D, 2020, Research on the Current Situation and Improvement of Innovation and Entrepreneurship Ability of College Students - A Case Study of G University. University Education, (2): $33-5$.

[3] Tang G, Wang Y, 2011, Research on the Cultivation Path of College Students' Innovation and Entrepreneurship Ability. Journal of Sichuan University of Science \& Engineering (Social Sciences Edition), 6(26): 76-9.

[4] Huang Z, Guo L, 2012, Core Issues in the Construction of Entrepreneurship Education Curriculum System in Colleges and Universities. Research in Educational Development, (19). 